\title{
Incorporation of Cement Bypass Dust in Hydraulic Road Binder
}

\author{
Nadezda Stevulova ${ }^{1, *} \mathbb{D}$, Julius Strigac ${ }^{2}$, Jozef Junak ${ }^{1}$, Eva Terpakova ${ }^{1} \mathbb{D}$ and Marian Holub ${ }^{1}$ \\ 1 Faculty of Civil Engineering, Institute of Environmental Engineering, Technical University of Kosice, \\ 04200 Kosice, Slovakia; jozef.junak@tuke.sk (J.J.); eva.terpakova@tuke.sk (E.T.); marian.holub@tuke.sk (M.H.) \\ 2 Povazska Cement Factory, 01863 Ladce, Slovakia; strigac.j@pcla.sk \\ * Correspondence: nadezda.stevulova@tuke.sk; Tel.: +421-55-602-4126
}

check for

updates

Citation: Stevulova, N.; Strigac, J.; Junak, J.; Terpakova, E.; Holub, M. Incorporation of Cement Bypass Dust in Hydraulic Road Binder. Materials 2021，14，41. https://dx.doi.org/ $10.3390 /$ ma14010041

Received: 27 November 2020

Accepted: 21 December 2020

Published: 24 December 2020

Publisher's Note: MDPI stays neutral with regard to jurisdictional claims in published maps and institutional affiliations.

Copyright: () 2020 by the authors. Licensee MDPI, Basel, Switzerland. This article is an open access article distributed under the terms and conditions of the Creative Commons Attribution (CC BY) license (https: / / creativecommons.org/ licenses/by/4.0/).

\begin{abstract}
This article describes utilization of a cement kiln bypass dust utilization as an added component in a hydraulic road binder. Three experimental binder mixes (BM1-BM3) with variation in the composition of the main constituents (cement clinker, ground limestone and ground granulated blast furnace slag) and constant content of bypass dust (10\%) were prepared under laboratory conditions. The properties of binder constituents, fresh experimental binder mixes and hardened specimens were tested according to STN EN 13282-2 for a normal hardening hydraulic road binder. The physical and chemical properties of all binder mixes (fineness: $+90 \mu \mathrm{m} \leq 15 \mathrm{wt} . \%$; $\mathrm{SO}_{3}$ content: $<4 \mathrm{wt} . \%$ ) met the standard requirements. The bypass dust addition led to an increase in the water content for standard consistency of cement mixes $(\mathrm{w} / \mathrm{c}=0.23)$ and to a shortening of the initial setting time for two experimental blended cement pastes (BM1 and BM3) compared with the value required by the standard. Only BM2 with the lowest $\mathrm{SO}_{3}$ content $(0.363 \mathrm{wt} . \%)$ and the highest percentage of granulated blast furnace slag $(9.5 \mathrm{wt} . \%)$ and alkalis $\left(\mathrm{Na}_{2} \mathrm{O}\right.$ and $\mathrm{K}_{2} \mathrm{O}$ content of $\left.5.9 \mathrm{wt} . \%\right)$ in the binder mix met the standard value for the initial setting time ( $\geq 150 \mathrm{~min})$. The results of compressive strength testing of experimental specimens after 56 days of hardening (59.2-63.9 MPa) indicate higher values than the upper limit of the standard requirement for the N4 class $(\geq 32.5 ; \leq 52.5 \mathrm{MPa})$.
\end{abstract}

Keywords: hydraulic road binder; cement; limestone; granulated blast furnace slag; bypass dust

\section{Introduction}

The sustainable construction industry focuses on the production of new environmentally friendly solutions connected with the replacement of conventional materials. Cement production is an intensive consumer of power, natural nonrenewable raw materials, and fossil fuels in a high-temperature process. The contribution of the cement manufacturing sector to the total global anthropogenic $\mathrm{CO}_{2}$ emissions is approximately $8 \%$ [1,2]. These environmental impacts are associated with $\mathrm{CO}_{2}$ emissions from clinker production (especially the thermal decomposition of calcium carbonate) and combustion of fossil fuels. $\mathrm{CO}_{2}$ is a greenhouse gas that contributes to global warming and related climate changes. Therefore, cement production urgently needs to apply the principle of sustainability and to use supplementary cementitious materials and substitutes for conventional fossil fuels when heating cement kilns through the use of alternative fuels with adequate calorific values. Recycling of appropriate products, such as waste and/or by-products, has become an attractive alternative to their disposal in accordance with the waste management hierarchy, as well as with European Union (EU) policies and Agenda 21 targets related to sustainable development. Benefits related to the usage of alternative fuels are associated with a reduction in environmental and economic burdens. Different types of gaseous, liqud, and solid wastes (hazardous and non-hazardous) are used as alternative fuels in cement kilns, such as waste gases from refinery, landfill, and pyrolysis, waste oils and fats, wax suspensions, chemical waste, asphalt slurry, industrial sludge, municipal sewage sludge, agricultural waste, rubber and tires, plastics, and textiles [3]. At present, attention is being paid to the replacement of fossil fuels with carbon neutral 
materials (agricultural biomass, municipal solid waste, or meat and bone from animalbased meals) [4]. The potential of these alternative fuels is related to their suitability for the combustion process and ensuring conditions of high-energy efficiency [5]. This strategy of the cement industry based on the partial substitution of traditional fossil fuels with alternative fuels for cement clinker production is of high importance and an attractive alternative to nonrenewable fossil fuels [4]. However, the use of alternative fuels must abide by the rules related to a reduction in $\mathrm{CO}_{2}$ emissions during the burning process in a cement kiln [6]. An increasing proportion of alternative fuels in the combustion process led to a need to implement bypass technology in production, thereby ensuring the removal of exhaust gases from the cement rotary kiln. Bypasses with different configurations are so far the only possible method of reducing the amount of chlorides in the cement kiln atmosphere [7,8]. Large quantities of particulate material present in the flue gases are removed from the kiln by air pollution control devices. Cement kiln dust (CKD), also known as bypass dust (BPD), is a finely dispersed particulate material, composed of oxidized, anhydrous, micron-sized particles accumulated in the dust collectors such as cyclones, bag houses, or electrostatic precipitators during the high-temperature Portland cement clinker process. This by-product containing fine particulates of unburned and partially burned raw materials is rich in alkalis, chlorides, and sulfates and may also contain heavy metals [9]. Alkaline chlorides are introduced to the cement kiln through the fuel. Thus, the chemical composition of BPD is determined by the clinker burning technology, the type of alternative fuel burned, the raw materials, and the exhaust gas removal system [10,11]. According to the Environmental Protection Agency (EPA) [12], BPD is considered as a potentially hazardous waste due to its caustic and irritating nature. Due to its high alkali content exceeding the cement clinker standard tolerances, the BPD by-product is not possible to return to the feedstock of clinker manufacturing. The amount of BPD generated per ton of clinker produced is equal to approximately $15-20 \%$ (by mass) [13-15]. The total volume of BPD generated in the Slovak Cement Factories is about $6 \%$ of the total annual production of clinker, which currently ends up in an on-site landfill for hazardous waste. High amounts of BPD per year lead to the high cost of collection, transportation, and landfilling due to a lack of adequate methods for its reuse and recycling. The existence of this waste and its growing production pose a serious environmental problem. Therefore, it is mandatory to minimize this by-product of cement production, or to handle it in a sustainable manner.

Literature sources indicate that BPD can be reused in a number of different ways for various purposes. As reported in many papers, the most common applications of BPD are in soil consolidation and stabilization $[10,16]$. BPD addition can lead to an increase in the shear strength of a soil and/or control the shrink-swell properties of a soil, thus improving the load-bearing capacity of a sub-grade to support pavements and foundations [17]. BPD combined with fly ash was successfully used for stabilizing road beds and, especially, clay soils [18]. Among modern engineering applications of BPD, its significant application potential and widespread utilization is in the construction sector. Mostly, BPD is applied as a partial replacement of cement in the production of mortar/concrete [10,19-22], cement bricks [23], concrete paving blocks [24,25], asphalt pavement/concrete [26], and sand sidewalks [9]. The presence of clinker phases and free lime in BPD may be responsible for its binding properties. Many papers reported the effect of used BPD on the different properties of mortar, and concrete $[10,21,22,27]$. There were a fewer older works devoted to the characterization of BPD and its influence on the properties, the results of which were summarized in [28]. Wide variation in the chemical composition of CKDs limits their potential application as a sustainable binder component in concrete. However, BPD application in suitable amounts is not adversely affecting their properties. As presented in [19], concretes with lower percentages of BPD (about $5 \%$ ) reach compressive strength, flexural strength, toughness, and freezing and thawing resistance comparable to the traditional concrete.

The presence of free $\mathrm{CaO}$ and significant amounts of soluble sodium and potassium compounds (chlorides and sulfates) in BPD causes its high alkalinity [29]. Thanks to BPD's alkaline nature, it can be used as an alkali activator of supplementary cementitious materi- 
als [30-32]. In recent years, many scientific advances in the preparation technology and the insights into the performances of new binders with a geopolymer matrix developed by blending BPDs with the fly ash and/or granulated blast furnace steel slag (GGBS) have performed [15,33,34]. As shown in [35], BPD addition enhances the geopolymerization reaction. The alkaline-modified alternative constituents improve the fresh mixture properties of the cement mortar/concrete and contribute to a reduction in the environmental impact. Successful utilization of BPD for fly ash and GGBS activation in ternary/quaternary cement system, leading to its higher strength, depends on the dissolution rate of additives, the alkalinity of the reacting system, and the existence of the optimum free lime and sulfate content [32,36]. In accordance with paper [37], the alkali activated cements are characterized by more durable geopolymer matrix and lower carbon footprint than ordinary Portland cement. Heikal et al. [31] reported on more durable binder with optimized mix composition of GGBS, BPD, and/or micro-silica, where 20\% BPD amount was used.

The incorporation of BPD in cement-blended material represents the most advanced strategy for an environmentally friendly waste management solution for BPD. Taking this aspect of BPD into account, alternative cement binder materials are becoming an important research topic.

Limited studies were aimed at evaluating the performance of cement mortars incorporating BPD and supplementary cementitious materials for infrastructure applications are currently available. Evaluation of the physico-mechanical and durability-related properties of concrete paving blocks containing BPD as a partial replacement or as an addition to cement indicated that up to $40-60 \%$ BPD could be used for producing environmentally friendly paving blocks for traffic applications [24]. As presented in [38], cement binders containing BPD can significantly improve the properties of the sub-grade.

BPD can be a constituent of cement binder with a high proportion of mineral components. A representative example is the hydraulic road binder. European standard requirements for a normal hardening hydraulic road binder refer to the physical and chemical properties of binder mixture, as well as the mechanical properties after 56 days of hardening. To the author's knowledge, there are few reports on the use of BPD in quaternary cement mixes but with a different composition for this purpose. Therefore, this study highlights its significance and originality.

Scientific hypothesis was supported by positive initial results that BPD containing a combination of the activators ( $\mathrm{CaO}$, and different forms of alkalis) can potentially result in a new binding system with favorable mechanical properties when used in conjunction with GGBS.

The main objective of the research was a comprehensive solution for the use of BPD in preparing experimental mixes for an eco-friendly normal hardening hydraulic road binder, with the key properties of fresh cement pastes and hardened specimens tested according to the standard in [39]. Another partial objective is to contribute to the available knowledge about adoption of alternative hydraulic road binder material that can significantly improve its performance with BPD addition for geopolymer formation in the binder system, and environmental protection. Therefore, the novelty of our research is in utilizing and evaluating the properties of a hydraulic road binder containing cement clinker and limestone as the major binder constituents with a portion of supplementary cement material (GGBS) and in combination with the additional substance of BPD. The scientific problem lies in understanding the influence of the physico-chemical characteristics of BPD on its performance as an effective binder component, and on the properties of fresh mixes and hardened mortar specimens. The outcome of this research is expected to provide critical information on the development of mortar properties in accordance with the standard requirements.

The choice of this additional binder constituent was motivated by the improvement in properties of the binder mix (mainly workability) in accordance with the standard in [39]. Three experimental mixes with variations in the main constituents (cement clinker and limestone) and GGBS were prepared. The BPD amount in the experimental mixtures was 
constant at $10 \%$ of the total weight in accordance with the standard recommended content of an additional binder constituent in normal hardening road binder. An additional aim of this research was to assess the critical properties, including the fineness, chemical and phase composition of dry binder mixes, the behavior of fresh mixes (initial setting time, consistency), and compressive strength of hardened bodies, and to interpret the obtained results. To achieve these aims, all standard requirements with respect to the properties of a normal hardening road binder were tested. The experimental investigations were organized in two phases. In the first, the properties of BPD and experimental binder mixtures were assessed in terms of their compliance with standard requirements for their mix composition. In the second, the resulting properties of fresh pastes and specimens hardened under normal conditions were evaluated.

\section{Materials and Methods}

\subsection{Input Materials of Hydraulic Binder Mix}

The source materials for the main constituents of the hydraulic road binder were as follows: Portland clinker, mineral additives in the form of ground limestone, and ground granulated blast furnace slag (GGBS). Cement kiln bypass dust (BPD) collected right at the cold end of the kiln in the cement plant and at the same time as the clinker was used as an additional constituent in the experimental binder mixtures. The chemical composition of the hydraulic binder constituents determined by X-ray fluorescence spectroscopy (XRF; SPECTRO iQ II XRF spectrometer, Ametek, Unterschleissheim, Germany) is given in Table $1 . \mathrm{Na}_{2} \mathrm{O}$ content was determined using flame photometry (Flame Photometer PFP7, JENWAY, Staffordshire, UK).

Table 1. Chemical composition of hydraulic binder constituents.

\begin{tabular}{|c|c|c|c|c|}
\hline \multirow{2}{*}{ Oxides } & Clinker & Limestone & GGBS & BPD \\
\hline & \multicolumn{3}{|c|}{ (wt.\%) } & \\
\hline $\mathrm{Na}_{2} \mathrm{O}$ & 0.24 & 0.07 & 0.58 & 5.44 \\
\hline $\mathrm{MgO}$ & 1.49 & 0.57 & 7.86 & 0.02 \\
\hline $\mathrm{Al}_{2} \mathrm{O}_{3}$ & 5.03 & 1.21 & 8.11 & 0.47 \\
\hline $\mathrm{SiO}_{2}$ & 20.67 & 5.82 & 42.28 & 1.92 \\
\hline $\mathrm{P}_{2} \mathrm{O}_{5}$ & 0.43 & 0.1 & 0.03 & 0.03 \\
\hline $\mathrm{SO}_{3}$ & 0.54 & 0.05 & 4.03 & 11.13 \\
\hline $\mathrm{Cl}^{-}$ & 0.03 & 0.02 & - & 33.69 \\
\hline $\mathrm{K}_{2} \mathrm{O}$ & 1.05 & 0.02 & 0.47 & 42.83 \\
\hline $\mathrm{CaO}$ & 65.18 & 51.95 & 36.52 & 7.05 \\
\hline $\mathrm{TiO}_{2}$ & - & - & 0.3 & - \\
\hline $\mathrm{MnO}$ & - & 0.04 & 0.78 & - \\
\hline $\mathrm{Fe}_{2} \mathrm{O}_{3}$ & 2.89 & 0.51 & 0.57 & 0.4 \\
\hline LOI * & 0.61 & 40.01 & 0.89 & 0.52 \\
\hline
\end{tabular}

LOI *-loss on ignition.

X-ray diffraction analysis was used for determination of the mineralogical composition of binder components (BRUKER AXS D8 Advance Diffractometer, Billerica, MA, USA). The main mineral phases identified in the binder constituents are listed in Table 2.

The particle size analysis of all hydraulic road constituents was performed separately using a laser granulometer (Mastersizer 2000; Malvern Instruments Ltd., Malvern, UK), because the standard sieving as one of the oldest particle sizing methods is widely used only for relatively large particles. The results of particle size analysis are shown in Table 3. The values of D10, D50, D90, specific surface area (S) and surface weighted mean (SM) describing the integral characteristics of the particle size distribution are summarized in Table 4. 
Table 2. Mineral phases of binder constituents.

\begin{tabular}{|c|c|}
\hline Binder Constituent & Mineral Phases \\
\hline Clinker & $\begin{array}{l}\text { Allite }\left(\mathrm{C}_{3} \mathrm{~S}\right) \text {, belite and larnite }\left(\mathrm{C}_{2} \mathrm{~S}\right), \mathrm{C}_{3} \mathrm{~A} \text { cubic (pure), } \mathrm{C}_{3} \mathrm{~A} \\
\text { orthorhombic }(\mathrm{Na} \text {-doped }) \text {, colville }\left(\mathrm{C}_{4} \mathrm{AF}\right) \text {, lime }(\mathrm{CaO}) \text {, periclase } \\
(\mathrm{MgO}) \text {, quartz }\left(\mathrm{SiO}_{2}\right) \text {, arcanite }\left(\mathrm{K}_{2} \mathrm{SO}_{4}\right) \text {, portlandite }\left(\mathrm{Ca}(\mathrm{OH})_{2}\right)\end{array}$ \\
\hline Limestone & Calcite $\left(\mathrm{CaCO}_{3}\right)$, dolomite $\left.\mathrm{CaMg}\left(\mathrm{CO}_{3}\right)_{2}\right)$, quartz $\left(\mathrm{SiO}_{2}\right)$ \\
\hline GGBS & $\begin{array}{l}\text { Melilite } \\
(\mathrm{Ca}, \mathrm{Na})_{2}\left(\mathrm{Al}, \mathrm{Mg}, \mathrm{Fe}^{2+}\right)(\mathrm{Si}, \mathrm{Al})_{2} \mathrm{O}_{7} \text {, merwinite } \mathrm{Ca}_{3} \mathrm{Mg}\left(\mathrm{SiO}_{4}\right)_{2}\end{array}$ \\
\hline BPD & $\begin{array}{l}\text { Sylvite }(\mathrm{KCl}) \text {, arcantite }\left(\mathrm{K}_{2} \mathrm{SO}_{4}\right) \text {, halite }(\mathrm{NaCl}) \text {, free lime }(\mathrm{CaO}) \text {, } \\
\text { quartz }\left(\mathrm{SiO}_{2}\right) \text {, anhydrite }\left(\mathrm{CaSO}_{4}\right)\end{array}$ \\
\hline
\end{tabular}

Table 3. Particle size analysis of binder constituents.

\begin{tabular}{|c|c|c|c|c|}
\hline \multirow{2}{*}{ Fraction $(\mu \mathrm{m})$} & Clinker & Limestone & GGBS & BPD \\
\hline & \multicolumn{3}{|c|}{ (wt.\%) } & \\
\hline $0-1$ & 4.86 & 16.56 & 3.42 & 11.56 \\
\hline $1-5$ & 19.72 & 32.73 & 14.68 & 48.52 \\
\hline $5-10$ & 16.57 & 10.12 & 15.25 & 22.56 \\
\hline $10-20$ & 15.67 & 10.12 & 20.97 & 9.22 \\
\hline $20-30$ & 7.63 & 8.18 & 14.36 & 4.19 \\
\hline $30-40$ & 9.60 & 6.46 & 8.49 & 2.20 \\
\hline $40-70$ & 8.56 & 7.48 & 7.58 & 1.65 \\
\hline 70-90 & 3.76 & 3.80 & 4.86 & - \\
\hline+90 & 3.63 & 4.55 & 10.39 & - \\
\hline
\end{tabular}

Table 4. Values of D10, D50, D90, specific surface area (S), and surface weighted mean (SM) representing integral characteristics of the particle size distribution of binder constituents.

\begin{tabular}{|c|c|c|c|c|c|}
\hline \multirow{2}{*}{$\begin{array}{c}\text { Binder } \\
\text { Constituent }\end{array}$} & D10 & D50 & D90 & \multirow{2}{*}{$\frac{S}{\left(m^{2} \cdot g^{-1}\right)}$} & \multirow{2}{*}{$\begin{array}{c}\text { SM } \\
(\mu \mathrm{m})\end{array}$} \\
\hline & & $(\mu \mathrm{m})$ & & & \\
\hline Clinker & 1.98 & 14.68 & 119.28 & 1.37 & 4.38 \\
\hline Limestone & 0.74 & 5.25 & 63.29 & 2.78 & 2.16 \\
\hline GGBS & 2.85 & 17.37 & 103.21 & 1.10 & 5.47 \\
\hline BPD & 0.86 & 4.13 & 15.59 & 2.88 & 2.08 \\
\hline
\end{tabular}

The $\mathrm{D}$ values refer to the distribution of constituents on the basis of their diameter (e.g., D50 denotes that half of the constituents are above and half are below this diameter).

\subsection{Hydraulic Binder Mix Composition}

According to the standard in [39], the content of the main binder constituents should be higher than $10 \%$ by weight, with the additional component not exceeding $10 \%$ of the total weight of the mixture in a normal hardening hydraulic road binder. Formulations for experimental mixtures were designed according to the recommended range of constituents for a normal hardening hydraulic binder according to the DoroCem product data sheet [40] with a constant content of BPD (Table 5).

Table 5. Recommended composition for a normal hardening hydraulic binder according to the DoroCem product data sheet [40].

\begin{tabular}{cccc}
\hline Clinker & Limestone & GGBS & BPD \\
\hline $58.5-71.5$ & (wt.\%) & & \\
\hline & $16.2-17.8$ & $6.5-9.5$ & 10 \\
\hline
\end{tabular}


The contents of individual constituents in the experimental binder mixtures BM1-BM3 are given in Table 6. BM1 features an average content of constituents (clinker, limestone, and GGBS) in the recommended range, whereas BM2 and BM3 feature the maximum and minimum levels of the recommended range, respectively.

Table 6. Design of recipes with varied constituents in the road binder mixtures.

\begin{tabular}{ccccc}
\hline \multirow{2}{*}{ Recipe } & Clinker & Limestone & GGBS & BPD \\
\cline { 2 - 5 } & & $\mathbf{( w t . \% )}$ & & \\
\hline BM1 & 65 & 17 & 8 & 10 \\
BM2 & 63 & 16.5 & 9.5 & 10 \\
BM3 & 67 & 17.5 & 6.5 & 10 \\
Referential & 100 & - & - & - \\
\hline
\end{tabular}

\subsection{Preparation of Blended Cement Pastes}

The introduction of BPD into the cement mixture necessitated an increase in the water required to obtain a cement paste of standard consistency. Due to the dry mixture and poor process ability of cement mixtures with a water coefficient $(\mathrm{w} / \mathrm{c})=0.5$, we had to optimize this ratio to a value of 0.23 . The reference mix and experimental binder pastes were prepared according to the standard in [41] by mixing of the dry binder components with deionized water in a standard E093 mixer (MATEST, Treviolo, Italy) at low speed for $120 \mathrm{~s}$. The mix was then stopped for $90 \mathrm{~s}$ to remove any paste adhering to the wall and bottom of the bowl, as well as to stirrer, using a plastic scraper. Mixing then continued at a higher speed for $120 \mathrm{~s}$.

A steel mold for three bodies with dimensions of $40 \times 40 \times 160 \mathrm{~mm}$ each was filled with fresh mix, and a laboratory vibrating table (MATEST, Treviolo, Italy) equipped with a motor generating 3000 vibrations per minute was used for compaction of the cement mortar specimens. Vibration continued until no air bubbles were present on the mortar surface and the body surface was relatively smooth with a glossy appearance. The vibrated fresh paste mixtures were stored in a humid environment (covered with polyethylene terephthalate (PET) foil) and, after $48 \mathrm{~h}$, the bodies were demolded and placed in an aqueous medium. Deionized water (from the laboratory of Faculty of Civil Engineering of TU in Kosice) was used for the processing of mixes according to [42]. Mixing and hardening processes were carried out in laboratory conditions (temperature of $23{ }^{\circ} \mathrm{C}$; relative humidity of 55-65\%).

\subsection{Testing Procedures}

\subsubsection{Fresh Mix Properties}

The setting times and the consistency of cement paste are key factors affecting the technological processes of mortars and concrete production. The initial setting time point was determined using the probe penetration method. The initial setting time for all fresh experimental cement pastes was determined as the time elapsed from zero to the moment when the distance between the cylindrical steel needle and the pad reached $6 \pm 3 \mathrm{~mm}$ according to the standard in [41] using a Vicat apparatus (ELE International, Sheffield, UK).

The consistency of experimental fresh binder mixes was determined using a flow table test in accordance with [43] for freshly mixed mortars including minerals binders, whereby the mean diameter of a test sample placed on a flow table was measured before being impacted vertically after release of a standard slump cone.

\subsubsection{Properties of Hardened Specimens}

The bulk density of the test specimens was evaluated according to [44]. The compressive strength of experimental cement specimens partially substituted with alternative binder constituents was determined according to [45] after 28, 56 and 90 days of hardening (ADR ELE 2000, International Ltd., UK). The resulting parameter values were the average 
of six measurements. The standard requirements for mechanical properties are provided in Table 7 as characteristic values of a normal hardening hydraulic road binder.

Table 7. Standard requirements for mechanical properties given as characteristic values.

\begin{tabular}{cccccc}
\hline \multirow{2}{*}{$\begin{array}{c}\text { Compressive } \\
\text { Strength }\end{array}$} & EN 196-1 & \multicolumn{4}{c}{ Requirement } \\
\cline { 2 - 6 } & Class & N1 * & N2 & N3 & N4 \\
\hline $\begin{array}{c}\text { after 56 Days } \\
{[\mathrm{MPa}]}\end{array}$ & Value range & $2.5-22.5$ & $12.5-32.5$ & $22.5-42.5$ & $32.5-52.5$ \\
\hline
\end{tabular}

* A load increase of $400 \pm 40 \mathrm{~N} / \mathrm{s}$ must be used when testing Class 1 test pieces.

\section{Results and Discussion}

\subsection{Properties of Dry Experimental Hydraulic Road Binder Mixes}

\subsubsection{Fineness}

The fineness of all hydraulic road constituents was determined separately due to the fact that we did not have a suitable homogenizer for preparing a dry mixture. As can be seen from Tables 3 and 4, the finest component was BPD, with particles no larger than $70 \mu \mathrm{m}$ and a D50 value of $4.13 \mu \mathrm{m}$. In contrast, the particle size distributions of ground limestone, clinker, and GGBS featured larger D10, D50 and D90 values. The specific surface area calculated from particle size analysis of the individual binder constituents ranged from 1.10 to $2.88 \mathrm{~m}^{2} \cdot \mathrm{g}^{-1}$, which correlated with the surface weighted mean diameter values in the range of 2.16-5.47 $\mu \mathrm{m}$. The surface characteristics of cement binder components related to their fineness, representing the surface available for hydration, were of following order: BPD $>$ limestone $>$ clinker $>$ GGBS.

The proportion of particles larger than $90 \mu \mathrm{m}$ in the binder constituents, as shown as shown in Table 8, met the standard requirement for the fineness of a normal hardening hydraulic road binder $(\leq 15 \%)$.

Table 8. Percentage of particles larger than 90 in the individual binder constituents and experimental binder mixes.

\begin{tabular}{ccccc}
\hline \multirow{2}{*}{ Binder Mix } & \multicolumn{4}{c}{ Proportion of Particles $+\mathbf{9 0} \boldsymbol{\mu m}[\mathbf{w t .} \%$ ] } \\
\cline { 2 - 5 } & Clinker & Limestone & GGBS & Binder Mix \\
\hline BM1 & 8.86 & 0.77 & 0.83 & 10.46 \\
BM2 & 8.59 & 0.8 & 0.99 & 10.38 \\
BM3 & 9.13 & 0.75 & 0.68 & 10.56 \\
\hline
\end{tabular}

\subsubsection{Chemical and Phase Composition}

As specified in [39], the standard requirements for the chemical properties of a normal hardening hydraulic road binder are a function of the sulfate content, expressed as $\mathrm{SO}_{3}$ percentage by weight, which should not exceed $4 \%$. The data in Table 1 confirm that the sulfate content in BPD was $11.13 \mathrm{wt} . \%$, while that in GGBS was $4.03 \mathrm{wt} . \%$. However, the calculated $\mathrm{SO}_{3}$ contents for the experimental hydraulic road binder mixes were lower than 4 wt.\% (Table 9).

Table 9. Sulfate content in experimental hydraulic road binder mixes.

\begin{tabular}{cc}
\hline Binder Mix & SO $_{3}[$ wt. $\%$ ] \\
\hline BM1 & 0.372 \\
BM2 & 0.363 \\
BM3 & 0.380 \\
\hline
\end{tabular}

Table 10 lists the $\mathrm{CaO}$ and $\mathrm{SiO}_{2}$ contents and $\mathrm{CaO} / \mathrm{SiO}_{2}$ ratio in the experimental binder mixtures. A CaO/ $/ \mathrm{SiO}_{2}$ ratio of approximately 3 ensures the formation of calcium 
silicate hydrates (C-S-H). The $\mathrm{Al}_{2} \mathrm{O}_{3}$ content in the experimental cement mixtures ranged from 3.09 to $4.17 \mathrm{wt} . \%$, thereby facilitating cement hydration to increase the strength of specimens (Table 11). The content of soluble alkalis, expressed as the sum of $\mathrm{Na}_{2} \mathrm{O}$ and $\mathrm{K}_{2} \mathrm{O}$ in the experimental mixtures (about 5.79-5.81 wt.\%), is required for the geopolymerization reaction. Lastly, free $\mathrm{CaO}$ or its hydrated form present in the clinker and BPD is able to participate in the pozzolana reaction with $\mathrm{SiO}_{2}$ and $\mathrm{Al}_{2} \mathrm{O}_{3}$. The contents of the individual oxides did not differ greatly in the experimental mixes.

Table 10. $\mathrm{CaO}$ and $\mathrm{SiO}_{2}$ content and their ratio in experimental binder mixes.

\begin{tabular}{cccccccc}
\hline \multirow{2}{*}{ Binder Mix } & Component & Clinker & Limestone & GGBS & BPD & $\Sigma$ & $\mathbf{C a O}_{\mathbf{3}} \mathbf{S i O}_{\mathbf{2}}$ \\
\cline { 3 - 8 } & & \multicolumn{7}{c}{ [wt.\%] } \\
\hline \multirow{2}{*}{$\mathrm{BM} 1$} & $\mathrm{CaO}$ & 42.25 & 8.83 & 2.92 & 0.70 & 54.70 & 3.04 \\
& $\mathrm{SiO}_{2}$ & 13.44 & 0.99 & 3.38 & 0.19 & 18.00 & \\
$\mathrm{BM} 2$ & $\mathrm{CaO}$ & 40.95 & 9.09 & 3.47 & 0.70 & 54.21 & 2.97 \\
& $\mathrm{SiO}_{2}$ & 13.02 & 1.02 & 4.02 & 0.19 & 19.25 & \\
$\mathrm{BM} 3$ & $\mathrm{CaO}$ & 43.55 & 8.57 & 2.37 & 0.70 & 55.14 & 3.11 \\
& $\mathrm{SiO}_{2}$ & 13.85 & 0.96 & 2.75 & 0.19 & 17.75 & \\
\hline
\end{tabular}

Table 11. $\mathrm{Al}_{2} \mathrm{O}_{3}, \mathrm{Na}_{2} \mathrm{O}$ and $\mathrm{K}_{2} \mathrm{O}$ contents in experimental binder mixes.

\begin{tabular}{ccccc}
\hline \multirow{2}{*}{ Binder Mix } & $\mathrm{Al}_{\mathbf{2}} \mathbf{O}_{\mathbf{3}}$ & $\mathbf{N a}_{\mathbf{2}} \mathbf{O}$ & $\mathbf{K}_{\mathbf{2}} \mathbf{O}$ & $\mathbf{N a}_{\mathbf{2}} \mathbf{O}+\mathbf{K}_{\mathbf{2}} \mathbf{O}$ \\
\cline { 2 - 5 } & & [wt. $\%$ ] & \\
\hline BM1 & 4.17 & 0.75 & 5.04 & 5.79 \\
BM2 & 3.09 & 0.87 & 5.03 & 5.90 \\
BM3 & 4.14 & 0.76 & 5.05 & 5.81 \\
\hline
\end{tabular}

A study of the mineralogical composition of the individual binder road constituents confirmed the presence of phases commonly occurring in these materials (Table 2). The $\mathrm{C}_{3} \mathrm{~S}$ phase was a major component in cement clinker (70.3 wt.\%), whereas the $\mathrm{C}_{2} \mathrm{~S}$ and $\mathrm{C}_{4} \mathrm{AF}$ contents ranged from 7.8 to $9.3 \mathrm{wt} . \%$. The percentage of the orthorhombic phase of $\mathrm{C}_{3} \mathrm{~A}$ was $6.4 \mathrm{wt} . \%$, while the cubic phase represented a lower content $(2.7 \mathrm{wt} . \%)$. The content of portlandite was about $1 \%$, with remaining phases having an even lower content.

The major phase in limestone was calcite, while minor crystalline phases were represented by dolomite and quartz.

GGBS as a ground by-product of iron and steel from a blast furnace was represented by a $\mathrm{Ca}-\mathrm{Mg}-\mathrm{Al}$ silicate glassy phase. $\mathrm{CaO}$ in GGBS tends to form disordered calcium/magnesium aluminosilicate, which is largely responsible for its reactivity during alkali activation [46]. The high $\mathrm{pH}$ of the alkaline activator promotes dissolution of GGBS, which drives the chemical reaction and strength development [47]. As is known [48], $\mathrm{Al}_{2} \mathrm{O}_{3}$ and $\mathrm{MgO}$ also play a role in the formation of alkali-activated GGBS paste.

\subsection{Properties of Fresh Cement Mixes \\ 3.2.1. Initial Setting Time}

Due to BPD fineness, its amount of $10 \mathrm{wt} . \%$ in the experimental binder mix caused an increase in water demand compared to traditional cement paste, in accordance with [49]. An average value of the water requirement for all mixes was $23 \mathrm{wt} . \%$. The initial setting times for the experimental fresh binder mixes determined as a function of the depth of needle penetration are given in Table 12. For the reference cement clinker paste, an initial setting time of $120 \mathrm{~min}$ was found, related to the cement class 32.5 specified in [50]. It was observed that the composition of experimental blended cement pastes BM1 and BM3 resulted in a shortening of their initial setting times compared to the standard [39] for a normal hardening hydraulic road binder $(\geq 150 \mathrm{~min})$. These results are consistent with findings in works $[19,51,52]$, where $10 \%$ BPD replacement of cement led to a decrease in 
the initial setting time. The lowest initial setting time value was identified for experimental blended cement paste BM3 (120 min), followed by experimental binder mixture BM1 (130 min). The shortening of the initial setting time can be caused by the content of alkalis that activates the hydration of clinker in binder mixes [53]. The decrease in the initial setting time with the higher water requirement for normal consistency in binder mixes indicates hydraulic properties of BPD.

Table 12. Depth of needle penetration for the reference and experimental hydraulic road binder mixes.

\begin{tabular}{ccccc}
\hline \multirow{2}{*}{ Time [min] } & \multicolumn{4}{c}{ Initial Setting Time Determined by Depth of Needle Penetration [mm] } \\
\cline { 2 - 5 } & Referential & BM1 & BM2 & BM3 \\
\hline 80 & - & 0 & 0 & 1 \\
90 & - & 1 & 1 & 2 \\
100 & 3 & 1 & 1 & 2 \\
105 & - & 1 & 1 & 3 \\
110 & - & 2 & 1 & 4 \\
115 & - & 3 & 2 & 5 \\
120 & 6 & 4 & 2 & 6 \\
125 & - & 5 & 2 & 7 \\
130 & - & 6 & 3 & 7 \\
140 & - & 7 & 6 & 9 \\
150 & - & 9 & & 10 \\
\hline
\end{tabular}

The initial setting time of BM2 (150 min) confirmed that only this binder mix met the standard value, likely related to the lowest $\mathrm{SO}_{3}$ content $(0.363 \mathrm{wt} . \%)$. Furthermore, the differences in the initial setting time could have been caused by the fineness of binder constituents in accordance with their inverse relationship [54].

\subsubsection{Consistency}

As shown in Table 13, all experimental cement blended pastes, including the reference paste, reached mean spill diameter values in the range $146-164.5 \mathrm{~mm}$, classifying them as plastic mortars (140-200 mm).

Table 13. Mean spillage values for the experimental hydraulic road binder mixes compared to the reference mix.

\begin{tabular}{lcccc}
\hline & Reference & BM1 & BM2 & BM3 \\
\hline Spill Diameter $[\mathrm{mm}]$ & 152 & 148 & 146 & 164.5 \\
\hline
\end{tabular}

Experimental pastes BM1 and BM2 showed a smaller spill diameter compared to the reference mix, whereas BM3 was more plastic with a higher spill diameter. BM1 was closest to the reference spill diameter value; however, the difference in values between BM1 and BM2 was only $2 \mathrm{~mm}$. The behavior of the binder mixes during the spill test is illustrated in Figure 1. In accordance with [55], the water to binder ratio, rate of hydration reactions and fineness of the binder materials mainly determines the consistency. It should be emphasized that the standard for a normal hardening hydraulic road binder [39] does not require a determination of consistency. 

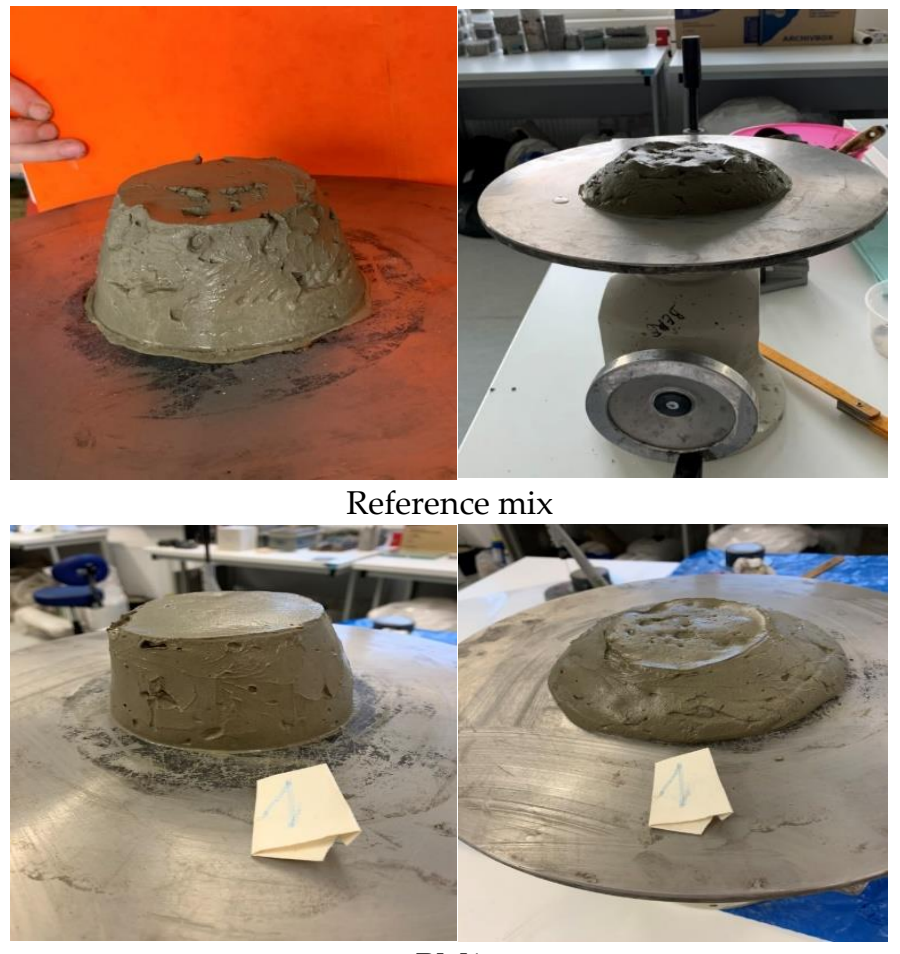

BM1

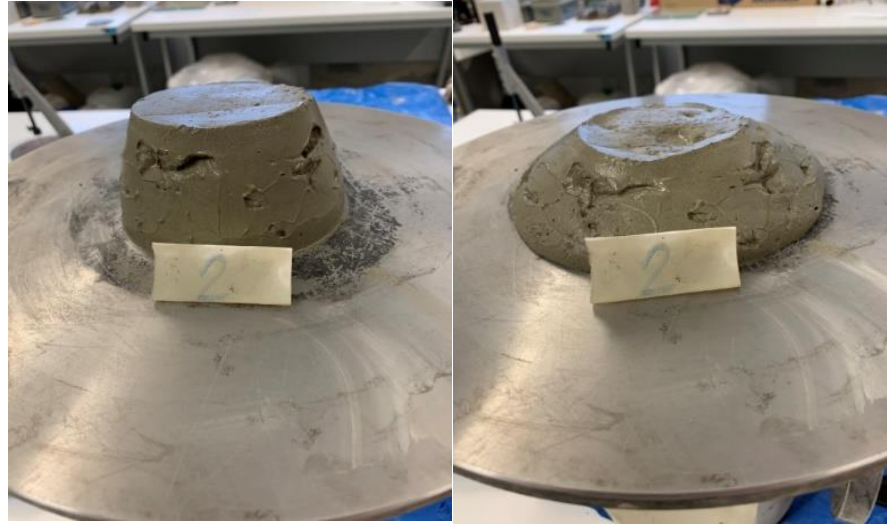

BM2

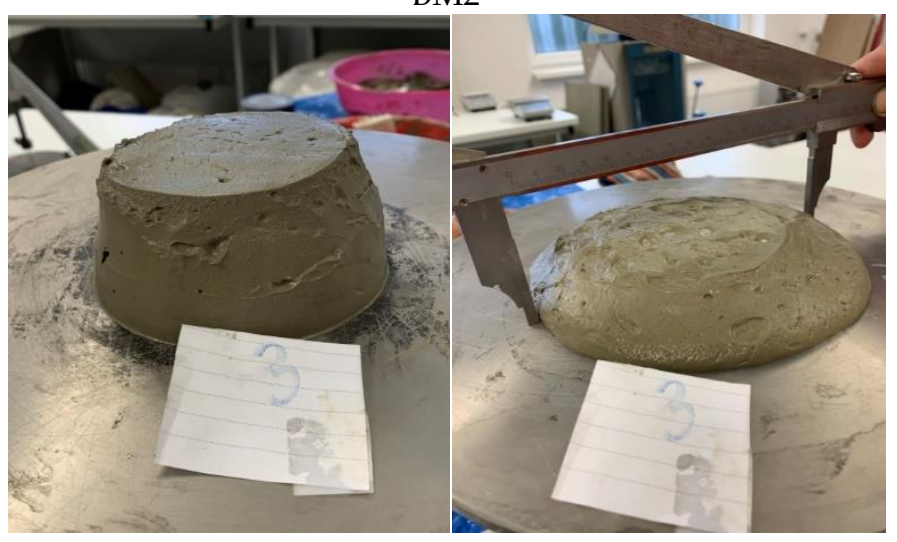

BM3

Figure 1. The behavior of the reference cement paste and experimental hydraulic road binder mixes during the spill test. 


\subsection{Properties of Hardened Specimens}

\subsubsection{Bulk Density}

The bulk density of the specimens after 28,56 , and 90 days of hardening is presented in Table 14. The bulk density of the reference bodies was lower than that of the mortars based on experimental hydraulic road binder mixes (BM1-BM3) depending on the hardening time. The results in Table 14 indicate that experimental binder mixes exhibited bulk density values in the range of $2100-2250 \mathrm{~kg} \cdot \mathrm{m}^{-3}$, consistent with the ordinary mortars $\left(1600-2300 \mathrm{~kg} \cdot \mathrm{m}^{-3}\right)$ [44].

Table 14. Bulk density of the hardened binder specimens.

\begin{tabular}{cccc}
\hline \multirow{2}{*}{ Specimens Sample } & \multicolumn{3}{c}{ Bulk Density $\left[\mathbf{k g} / \mathbf{m}^{\mathbf{3}}\right]$} \\
\cline { 2 - 4 } & 28 Days & 56 Days & 56 Days \\
\hline Reference & $2190 \pm 18$ & $2090 \pm 12$ & $2120 \pm 7$ \\
BM1 & $2250 \pm 23$ & $2140 \pm 16$ & $2188 \pm 8$ \\
BM2 & $2217 \pm 3$ & $2100 \pm 8$ & $2147 \pm 11$ \\
BM3 & $2170 \pm 5$ & $2160 \pm 10$ & $2150 \pm 8$ \\
\hline
\end{tabular}

\subsubsection{Compressive Strength}

The compressive strength after 28, 56 and 90 days of hardening for experimental binder mixes prepared at a constant water-to-binder ratio of 0.23 with varied the binder constituents and constant addition of BPD is presented in Figure 2. The variation in the measured compressive strength values of each hardened mortar sample was about $\pm 10 \%$. The lowest variance of the strength parameter $( \pm 5 \%)$ was recorded for the BM1 sample with the highest values of compressive strength after hardening compared to other mortar samples.

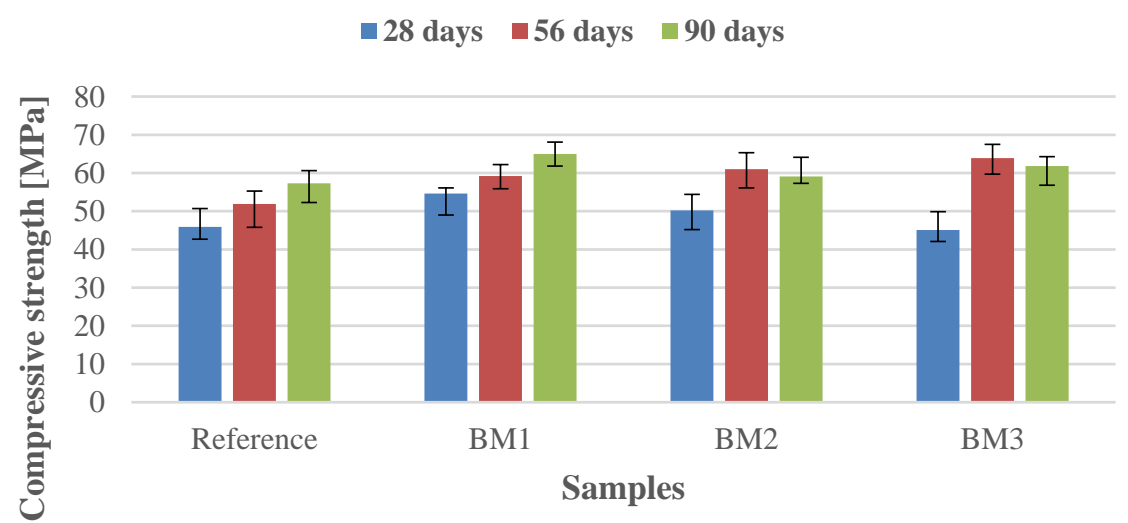

Figure 2. Compressive strength of reference and experimental specimens after 28, 56, and 90 days of hardening.

A comparison of the values (shown in Figure 2) demonstrates that the compressive strength increased with hardening time. All experimental specimens after 56 days of hardening reached higher strength values (59.2-63.9 MPa) than the reference sample (51.90 MPa). The BM3 sample achieved the highest value of compressive strength, where the main binder constituents in the mixture (clinker, limestone, and GGBS) were at the minimum level of the recommended range for the DoroCem product. High compressive strength values (60-69 MPa) of quaternary mixes consisting of $30 \mathrm{wt} . \%$ Portland cement, $45-50$ wt. $\%$ fly ash, 5-10 wt.\% BPD, and 15-18.5 wt.\% GGBS after 28 days of hardening were achieved [56].

The relative compressive strength calculated as the ratio of the compressive strength value of experimental specimens BM1-BM3 and the reference sample (Table 15), showed an increasing trend of $14-23 \% 56$ days. 
Table 15. Relative compressive strengths of hardened test specimens.

\begin{tabular}{cccc}
\hline \multirow{2}{*}{ Specimen } & \multicolumn{3}{c}{ Relative Compressive Strengths after Hardening } \\
\cline { 2 - 4 } & 28 Days & 56 Days & 90 Days \\
\hline BM1 & 1.19 & 1.14 & 1.15 \\
BM2 & 1.09 & 1.17 & 1.03 \\
BM3 & 0.98 & 1.23 & 1.08 \\
\hline
\end{tabular}

The compressive strength after 56 days of hardening is a key factor in meeting standard requirements for the mechanical properties of a normal hardening hydraulic binder. As specified in [39], for class $\mathrm{N} 4$ (Table 2), this value should be in the range of 32.5 to $52.5 \mathrm{MPa}$. The measured values of compressive strength for experimental specimens after 56 days of hardening ( 59.2 to $63.9 \mathrm{MPa}$ ) were 13-21.6\% higher than the upper limit of the range for class N4. The BM3 sample with the highest $\mathrm{CaO} / \mathrm{SiO}_{2}$ ratio (3.11 wt.\%) achieved the highest increase in compressive strength $(21.6 \%)$ compared with the reference specimen.

The high strength found for the experimental binder specimens can be attributed to the hydration of the clinker as well as the geopolymeric compounds formed in the binder mix consisting of limestone, GGBS, and BPD. As is known, hydration involves a complex group of reactions causing changes in the chemical and physico-mechanical properties of the system, particularly in the setting and hardening of the binder mix. This process is sensitive to many factors of a physical and chemical nature. One of the critical factors in attaining the final strength of a binder in allowable time is its particle size distribution. A smaller particle size results in a greater surface area-to-volume ratio, with more area available for water-cement and binder particle interactions per unit volume. Therefore, finer binder materials react faster with water molecules, resulting in a higher rate of strength development.

On the other hand, the chemical composition of the binder also plays an important role in the formation of various hydrated phases. The clinker composition is of special relevance, whereby the presence of free $\mathrm{CaO}$ in the binder mix is very important for the formation of the main hydration products of C-S-H and C-S-A-H. The strength of specimens was significantly affected by the relatively high content of free $\mathrm{CaO}$ in BPD capable of rapid hydration to $\mathrm{Ca}(\mathrm{OH})_{2}$ and a subsequent pozzolanic reaction with the active components of $\mathrm{SiO}_{2}$ and $\mathrm{Al}_{2} \mathrm{O}_{3}$ present in GGBS. Sodium and potassium oxides present in the binder mix are important for the formation of silicon-based geopolymers $\left(\mathrm{Men}\left[-\left(\mathrm{SiO}_{2}\right)_{\mathrm{z}}-\mathrm{AlO}_{2}\right]_{\mathrm{n}} \cdot \mathrm{wH}_{2} \mathrm{O}\right.$; $\mathrm{Me}=\mathrm{Na}^{+}$or $\left.\mathrm{K}^{+}\right)$as well as for the creation of $\mathrm{n} 1 \mathrm{Na}_{2} \mathrm{O} \cdot \mathrm{n} 2 \mathrm{CaO} \cdot \mathrm{n} 3 \mathrm{SiO}_{2} \cdot \mathrm{n}_{4} \mathrm{H}_{2} \mathrm{O}$ [57].

Calcium monosulfoaluminate hydrate (AFm phase) and ettringite (AFt phase) are commonly present in cements. The crystalline structure of AFm phases allows the incorporation of one monovalent anion or half of a divalent anion in the interlayers. In contrast with AFt phases, AFm phases are characterized by a better ability to bind chloride ions. It is known that the chloride- binding capacity in cement paste can also contribute to the formation of specific hydrated phase such as Friedel's salt $\left(3 \mathrm{CaO} \cdot \mathrm{Al}_{2} \mathrm{O}_{3} \cdot \mathrm{CaCl}_{2} \cdot 10 \mathrm{H}_{2} \mathrm{O}\right)$ [58]. The presence of sulfate ions in the binder mix leads to the formation of Kuzel's salt in which chloride ions are partially substituted by sulfate ions $\left(3 \mathrm{CaO} \cdot \mathrm{Al}_{2} \mathrm{O}_{3} \cdot 0.5 \mathrm{CaSO}_{4} \cdot 0.5 \mathrm{CaCl}_{2} \cdot 11 \mathrm{H}_{2} \mathrm{O}\right)[59]$, while ferro-aluminosilicate with repeating units of (-Fe-O-Si-O-Al-O-) can also be formed. There is also a possibility to form further other hydration products including calcium aluminateferrite hydrate- $\mathrm{Ca}_{2}(\mathrm{Al}, \mathrm{Fe})(\mathrm{OH})_{6}$ - and hydrotalcite $\left.\mathrm{Mg}_{6} \mathrm{Al}_{2} \mathrm{CO}_{3}(\mathrm{OH})_{16} \cdot 4 \mathrm{H}_{2} \mathrm{O}\right)[60]$.

The mechanism of underlying alkali-activation of commercial granulated blast furnace slag is still not fully understood in the existing literature. The composition and mineralogy of raw pozzolans are critical in the formulation of alkali-activated geopolymer materials. The alkali-activation of GGBS products mixed with 3.5-5.5 wt.\% sodium hydroxide or water glass yields a low-basic, highly amorphous C-S-H gel product possessing high aluminum content [61]. BPD is an excellent alkaline activator enhancing the dissolution of $\mathrm{Si}$ - and Al-containing GGBS [31]. It is assumed that the $\mathrm{Si-O}-\mathrm{Si}, \mathrm{Al}-\mathrm{O}-\mathrm{Al}$ and $\mathrm{Al}-\mathrm{O}-\mathrm{Si}$ bonds in the aluminosilicate, silicate, and/or aluminate solids are broken first and the 
dissolution into alumina silicate species and together with alkali cations polymerize and produce the geopolymer network. Consequently, the precipitation of formed hydration products occurs in the form of sodium (or potassium) -aluminosilicate-hydrate similar to natural zeolites (Na-A-S-H or K-A-S-H) in the experimental binder mix [62]. In the final hardening phase of the matrix, excess water exclusion occurs, and a three-dimensional zeolite structure-analogous semi-amorphous phase is formed. In this structure, $\left[\mathrm{SiO}_{4}\right]^{4-}$ and $\left[\mathrm{AlO}_{4}\right]^{5-}$ tetrahedrons are linked by bridging oxygen with the charge imbalance compensated for sodium and potassium cations [63]. These arguments support the above discussion regarding the composition of experimental binder mixes with respect to their mechanical properties.

\section{Conclusions}

According to the evaluation of results obtained from experiments with respect to the standard requirements for a normal hardening hydraulic road binder, the following conclusions can be made:

(1) Verifying the designed composition and properties of experimental binder mixes showed the possibility of producing a normal hardening hydraulic road binder using clinker, ground limestone and ground granulated blast furnace slag with an additional component of cement kiln bypass dust not exceeding $10 \%$ of the total weight of the mix. The standard requirements for the physical and chemical properties of the experimental binder mixes can be considered fulfilled on the basis of their evaluation, as a function of the fineness, sulfate content, and initial setting time.

(1.1) The fineness of the binder mixes met the standard requirement with the proportion of particles larger than $90 \mu \mathrm{m}$ being $\leq 15 \mathrm{wt} . \%$.

(1.2) The sulfate content expressed as $\mathrm{SO}_{3}$ did not exceed the standard limit of $4 \mathrm{wt} . \%$ in all experimental binder mixes; in fact, it was 10 times lower.

(1.3) The standard requirement for the initial setting time ( $\geq 150 \mathrm{~min})$ was only met by the experimental cement blended paste $\mathrm{BM} 2$ with the lowest $\mathrm{SO}_{3}$ content. The binder mix contained the lowest proportion of clinker and the highest proportion of ground limestone and GGBS among the tested mixes.

(2) The compressive strengths of all experimental specimens reached a higher strength after 56 days of hardening than that specified in the standard STN EN 13282-2 for class $\mathrm{N} 4(\geq 32.5 \mathrm{MPa}, \leq 52.5 \mathrm{MPa})$, exceeding the upper limit of the range by $13-21.6 \%$. According to the literature, we hypothesized that the high compressive strength values were due to the resulting structure of geopolymer products.

According to the preliminary results, it can be concluded that the cement kiln bypass dust can be used as an additional component in a normal hardening hydraulic road binder $(<10 \mathrm{wt} . \%)$. Although the substitution of cement with supplementary cementitious materials (GGBS and BPD) brings both environmental and economic benefits for the cement industry, this research area needs to be expanded to include other important properties to avoid any adverse effects related to the degradation of such a road binder (e.g., volume stability, water absorption, and frost and chemical resistance). Therefore, our further research will focus on a deeper study of the microstructure and durability of this hydraulic binder, thereby contributing to an increase in the complex knowledge of its properties.

Author Contributions: N.S., conceptualization, investigation, supervision, methodology, formal analysis, validation, writing - original draft, and writing-review and editing; J.S., conceptualization, formal analysis, validation, and writing-review and editing; J.J., methodology, formal analysis, validation, and writing-review and editing; E.T., methodology, formal analysis, validation, and writing-review and editing; M.H., methodology. All authors have read and agreed to the published version of the manuscript.

Funding: This research was funded by the Agency of the Ministry of the Education, Science, Research and Sport of the Slovak Republic, grant number VEGA 1/0222/19. 
Data Availability Statement: The data presented in this study are available on request from the corresponding author.

Acknowledgments: The authors thank the Povazska Cement Factory Ltd. in Ladce for their cooperation and provision of materials (clinker, ground limestone, ground granulated blast furnace slag, and cement bypass dust and for very good cooperation.

Conflicts of Interest: The authors declare no conflict of interest.

\section{References}

1. Mikulčič, H.; Klemeš, J.J.; Vujanovič, M.; Urbaniec, K.; Duič, N. Reducing greenhouse gasses emissions by fostering the deployment of alternative raw materials and energy sources in the cleaner cement manufacturing process. J. Clean. Prod. 2016, 136, 119-132. [CrossRef]

2. Andrew, R.M. Global $\mathrm{CO}_{2}$ emissions from cement production. Earth Syst. Sci. Data 2018, 10, 195-217. [CrossRef]

3. Chinyama, M.P.M. Alternative Fuels in Cement Manufacturing (Chapter 11). In Alternative Fuel, 1st ed.; Manzanare, M., Ed.; IntechOpen: London, UK, 2011. [CrossRef]

4. Georgiopoulou, M.; Lyberatos, G. Life cycle assessment of the use of alternative fuels in cement kilns: A case study. J. Environ. Manag. 2018, 216, 224-234. [CrossRef] [PubMed]

5. European Commission; BAT. Best Available Techniques (BAT) Reference Document for the Production of Cement, Lime and Magnesium Oxide. Industrial Emissions Directive 2010/75/EU (Integrated Pollution Prevention and Control); Joint Research Centre, Institute for Prospective Technological Studies, Sustainable Production and Consumption, Unit European IPPC Bureau: Luxembourg, 2013.

6. Cement Sustainability Initiative. Guidlines for Co-Processing Fuels and Raw Materials in Cement Manufacturing (Version 2), WBCSD. 2014. Available online: http://www.wbcsdcement.org/index.php/en/key-issues/fuels-materials/guidlines-forselection (accessed on 27 November 2020).

7. Schneider, M. Technology developments in the cement industry. In Proceedings of the 7th International VDZ Congress 2013, Düsseldorf, Germany, 25-27 September 2013; Verlag Bau + Technik GmbH: Erkrath, Germany, 2013; pp. 1-6, ISBN 3764005831.

8. Strigac, J. Effect of selected alternative fuels and raw materials on the cement clinker quality. SSP J. Civ. Eng. 2015, 10, 81-92. [CrossRef]

9. Siddique, R.; Kunala; Mehta, A. Utilization of industrial by-products and natural ashes in mortar and concrete development of sustainable construction materials. In Nonconventional and Vernacular Construction Materials Characterisation, Properties and Applications, 2nd ed.; Woodhead Publishing (Series in Civil and Structural Engineering): Cambridge, UK, 2020; pp. 247-303. [CrossRef]

10. Ashteyat, A.M.; Haddad, R.H.; Obaidat, Y.T. Case study on production of self compacting concrete using white cement by pass dust. Case Stud. Constr. Mater. 2018, e00190. [CrossRef]

11. Barnat-Hudek, D.; Góra, J.; Suchorab, Z.; Łagód, G. Cement kiln dust (Chapter 5). In Waste and Supplementary Cementitious Materials in Concrete. Characterisation, Properties and Applications, 1st ed.; Sissique, R., Cachim, P., Eds.; Woodhead Publishing: Cambridge, UK, 2018; pp. 149-180. [CrossRef]

12. Environmental Protection Agency. Management Standards Proposed for Cement Kiln Dust Waste; EPA 530-F-99-023; Environ-Mental Fact Sheet: Chapel Hill, NC, USA, 1999.

13. Van Oss, H.G.; Padovani, A.C. Cement manufacture and the environment, part II: Environmental challenges and opportunities. J. Ind. Ecol. 2003, 7, 93-127. [CrossRef]

14. Saleh, H.M.; El-Saied, F.A.; Salaheldin, T.A.; Hezo, A.A. Influence of severe climatic variability on the structural, mechanical and chemical stability of cement kiln dust-slag-nanosilica composite used for rad waste solidification. Constr. Build. Mater. 2019, 218, 556-567. [CrossRef]

15. Arulrajah, A.; Mohammadinia, A.; D'Amico, A.; Horpibulsuk, S. Cement kiln dust and fly ash blends as an alternative binder for the stabilization of demolition aggregates. Constr. Build. Mater. 2017, 145, 218-225. [CrossRef]

16. Adeyanju, E.A.; Okeke, C.A. Clay oil stabilization using cement kiln dust. IOP Conf. Ser. Mater. Sci. Eng. 2019, 640, 1-10. [CrossRef]

17. Elbaz, A.A.; Aboulfotoh, A.M.; Dohdoh, A.M.; Wahba, A.M. Review of beneficial uses of cement kiln dust (CKD), fly ash (FA) and their mixture. J. Mater. Environ. Sci. 2019, 10, 1062-1073.

18. Yoobanpot, N.; Jamsawang, P.; Horpibulsuk, S. Strength behavior and microstructural characteristics of soft clay stabilized with cement kiln dust and fly ash residue. Appl. Clay Sci. 2017, 141, 146-156. [CrossRef]

19. Maslehuddin, M.; Al-Amoudi, O.; Rahman, M.; Ali, M.; Barry, M. Properties of cement kiln dust concrete. Constr. Build. Mater. 2009, 23, 2357-2361. [CrossRef]

20. Al-Jabri, K.; Taha, R.; Al-Hashmi, A.; Al-Harthy, A. Effect of copper slag and cement by-pass dust addition on mechanical properties of concrete. Constr. Build. Mater. 2006, 20, 322-331. [CrossRef]

21. Marku, J.; Dumi, I.; Lico, E.; Dilo, T.; Cakaj, O. The characterization and the utilization of cement kiln dust (CKD) as partial replacement in mortar and concrete production. Zast. Mater. 2012, 53, 334-344.

22. Shubbar, A.A.; Jafer, H.; Abdulredha, M.; Al-Khafaji, Z.S.; Nasr, M.S.; Al Masoodi, Z.; Sadique, M. Properties of cement mortar incorporated high volume fraction of GGBFS and CKD from 1 day to 550 days. J. Build. Eng. 2020, 30, 101327. [CrossRef] 
23. El-Attar, M.M.; Sadek, D.M.; Salah, A.M. Recycling of high volumes of cement kiln dust in bricks industry. J. Clean. Prod. 2017, 143, 506-515. [CrossRef]

24. Sadek, D.M.; El-Attar, M.M.; Ali, A.M. Physico-mechanical and durability characteristics of concrete paving blocks incorporating cement kiln dust. Constr. Build. Mater. 2017, 157, 300-312. [CrossRef]

25. Abdel-Ghani, N.T.; El-Sayed, H.A.; El-Habak, A.A. Utilization of by-pass cement kiln dust and air-cooled blast furnace steel slag in the production of some "green" cement products. HBRC J. 2018, 14, 408-414. [CrossRef]

26. Modarres, A.; Ramyar, H.; Ayar, P. Effect of cement kiln dust on the low-temperature durability and fatigue life of hot mix asphalt. Cold Reg. Sci. Technol. 2015, 110, 59-66. [CrossRef]

27. Saleh, H.M.; El-Saiedb, F.A.; Salaheldin, T.A.A.; Hezo, A. Macro- and nanomaterials for improvement of mechanical and physical properties of cement kiln dust-based composite materials. J. Clean. Prod. 2018, 204, 532-541. [CrossRef]

28. Tkaczewska, E. The influence of cement bypass dust on the properties of cement curing under normal and autoclave conditions. Struct. Environ. 2019, 11, 5-22. [CrossRef]

29. Czapik, P.; Zapala-Slawete, J.; Owsik, Z.; Stepieň, P. Hydration of cement by-pass dust. Constr. Build. Mater. 2020, 231, 117139. [CrossRef]

30. Kalina, L.; Bílek, V., Jr.; Kiripolský, T.; Novotný, R.; Másilko, J. Cement kiln by-pass dust: An effective alkaline activator for pozzolanic materials. Materials 2018, 11, 1770. [CrossRef] [PubMed]

31. Heikal, M.; Zaki, M.E.A.; Ibrahim, S.M. Preparation, physico-mechanical characteristics and durability of eco-alkali-activated binder from blast-furnace slag, cement kiln-by-pass dust and microsilica ternary system. Constr. Build. Mater. 2020, $260,119947$. [CrossRef]

32. Chaunsali, P.; Peethamparan, S. Evolution of strength, microstructure and mineralogical composition of a CKD-GGBFS binder. Cem. Concr. Res. 2011, 41, 197-208. [CrossRef]

33. Zhuang, X.Y.; Chena, L.; Komarneni, S.; Zhoua, C.H.; Tonga, D.S.; Yang, H.M.; Yu, W.H.; Wang, H.H. Fly ash-based geopolymer: Clean production, properties and applications. J. Clean. Prod. 2016, 125, 253-267. [CrossRef]

34. Chaunsali, P.; Peethamparan, S. Influence of the composition of cement kiln dust on its interaction with fly ash and slag. Cem. Concr. Res. 2013, 54, 106-113. [CrossRef]

35. Sultan, M.E.; Abo-El-Eneinb, S.A.; Sayeda, A.Z.; EL-Sokkaryc, T.M.; Hammada, H.A. Incorporation of cement bypass flue dust in fly ash and blast furnace slag-based geopolymer. Case Stud. Constr. Mater. 2018, 8, 315-322. [CrossRef]

36. Konsta-Gdoutos, M.S.; Shah, S.P. Hydration and properties of novel blended cements based on cement kiln dust and blast furnace slag. Cem. Concr. Res. 2003, 33, 1269-1276. [CrossRef]

37. Gartner, E.; Hirao, H. A review of alternative approaches to the reduction of $\mathrm{CO}_{2}$ emissions associated with the manufacture of the binder phase in concrete. Cem. Concr. Res. 2015, 78, 126-142. [CrossRef]

38. Lachemi, M.; Sahmaran, M.; Hossain, K.M.A.; Lofty, A.; Shehata, M. Properties of controlled low strength materials incorporating cement kiln dust and slag. Cem. Concr. Compos. 2010, 32, 623-629. [CrossRef]

39. STN EN 13282-2. Hydraulic Road Binders-Part 2: Normal Hardening Hydraulic Road Binders-Composition, Specifications and Conformity Criteria; Slovak Office of Standards, Metrology and Testing: Bratislava, Slovakia, 2015.

40. Available online: https://crh-white.com/wp-content/uploads/Product_documentation/SpecialneSpojiva/dorocem-turňa.pdf (accessed on 27 November 2020).

41. STN EN 196-3. Methods of Testing Cement_Part 3: Determination of Setting Times and Soundness; Slovak Office of Standards, Metrology and Testing: Bratislava, Slovakia, 2017.

42. STN EN 1008. Mixing Water for Concrete. Specification for Sampling, Testing and Assessing the Suitability of Water, including Water Recovered from Processes in the Concrete Industry, as Mixing Water for Concrete; Slovak Office of Standards, Metrology and Testing: Bratislava, Slovakia, 2003.

43. STN EN 1015-3. Methods of Test for Mortar for Masonry_Part 3: Determination of Consistence of Fresh Mortar (by Flow Table); Slovak Office of Standards, Metrology and Testing: Bratislava, Slovakia, 2007.

44. STN EN 12390-7. Testing Hardened Concrete. Density of Hardened Concrete; Slovak Office of Standards, Metrology and Testing: Bratislava, Slovakia, 2020.

45. STN EN 12390-7. Methods of Testing Cement_Part 1: Determination of Strength; Slovak Office of Standards, Metrology and Testing: Bratislava, Slovakia, 2019.

46. Li, C.; Sun, H.; Li, L. A review: The comparison between alkali-activated slag $(\mathrm{Si}+\mathrm{Ca})$ and metakaolin $(\mathrm{Si}+\mathrm{Al})$ cements. Cem Concr. Res. 2010, 40, 1341-1349. [CrossRef]

47. Criado, M.; Walkley, B.; Ke, X.; Provis, J.L.; Bernal, S.A. Slag and Activator Chemistry Control the Reaction Kinetics of Sodium Metasilicate-Activated Slag Cements. Sustainability 2018, 10, 4709. [CrossRef]

48. Gong, K.; White, C.E. Impact of chemical variability of ground granulated blast-furnace slag on the phase formation in alkaliactivated slag pastes. Cem. Concr. Res. 2016, 89, 310-319. [CrossRef]

49. Heikal, M.; Aiad, I.; Helmy, I.M. Portland cement clinker, granulated slag and by-pass cement dust composites. Cem. Concr. Res. 2002, 32, 1805-1812. [CrossRef]

50. STN EN 197-1. Cement. Part 1: Composition, Specifications and Conformity Criteria for Common Cements; Slovak Office of Standards, Metrology and Testing: Bratislava, Slovakia, 2012. 
51. El-Aleem, S.A.; Abd-El-Azis, M.A.; Heikal, M.; El-Didamony, H. Effect of cement kiln dust substitution on chemical and physical properties and compressive strength of portland and slag cements. Arab. J. Sci. Eng. 2005, 30, 263-273.

52. Farhan, S.; Sharif, A. Influence of cement kiln dus tas partial replacement on some properties of ordinary and white Portland cement. Tikrit J. Eng. Sci. 2011, 18, 23-32.

53. Khalil, K.A.; Abd-El-Hameed, N.M. Physicochemical characteristic of slag rich cement pastes incorporated by-pass cement dust. Egypt. J. Chem. 2016, 59, 494-507. [CrossRef]

54. Higginson, E. The Effect of Cement Fineness on Concrete. In Fineness of Cement; ASTM International: West Conshohocken, PA, USA, 1970; pp. 71-81. [CrossRef]

55. Dave, N.; Misra, A.K.; Srivastava, A.; Kaushik, S.K. Experimental analysis of strength and durability properties of quaternary cement binder and mortar. Constr. Build. Mater. 2016, 107, 117-124. [CrossRef]

56. Sadique, M.; Coakley, E. The influence of physico-chemical properties of fly ash and CKD on strength generation of high-volume fly ash concrete. Adv. Cem. Res. 2016, 28, 595-605. [CrossRef]

57. Wang, W.; Noguchi, T. Alkali-silica reaction (ASR) in the alkali-activated cement (AAC) system: A state-of-the-art review. Constr. Build. Mater. 2020, 252, 119105. [CrossRef]

58. Balonis, M.; Lothenbach, B.; Le Saout, G.; Glasser, F.P. Impact of chloride on the mineralogy of hydrated Portland cement systems. Cem. Concr. Res. 2010, 40, 1009-1022. [CrossRef]

59. Mesbah, A.; François, M.; Cau-dit-Comes, C.; Frizon, F.; Filinchuk, F.; Leroux, F.; Ravaux, J.; Renaudin, G. Crystal structure of Kuzel's salt $3 \mathrm{CaO} \cdot \mathrm{Al}_{2} \mathrm{O}_{3} \cdot 1 / 2 \mathrm{CaSO}_{4} \cdot 1 / 2 \mathrm{CaCl}_{2} \cdot 11 \mathrm{H}_{2} \mathrm{O}$ determined by synchrotron powder diffraction. Cem. Concr. Res. 2011, 41, 504-509. [CrossRef]

60. Osama, A.M. A Review of Durability and Strength Characteristics of Alkali-Activated Slag Concrete. Materials 2019, 12, 1198. [CrossRef]

61. Petermann, J.C.; Saeed, A.; Hammons, M.I. Alkali-Activated Geopolymers: A Literature Review; AFRL-RX-TY-TR-2010-0097 Air Force Research Laboratory: Panama City, FL, USA, 2010; p. 8.

62. Provis, J.L.; Van Deventer, J.S.J. Geopolymers: Structures, Processing, Properties and Industrial Applications, 1st ed.; Woodhead Publishing: Sawston, UK, 2009; ISBN 9781845694494.

63. Provis, J.L.; Hajimohammadi, A.; White, C.E.; Bernal, S.A.; Myers, R.J.; Winarski, R.P.; Rose, V.; Proffen, T.E.; Llobet, A.; van Deventer, J.S.J. Nanostructural characterization of geopolymers by advanced beamline techniques. Cem. Concr. Compos. 2013, 36, 56-64. [CrossRef] 